\title{
Chapter 21 \\ Sidestepping Rights: An Analysis \\ of the Intersection of Human Rights \\ Obligations and Their Practical \\ Implications for Older Migrants
}

\author{
Ada Lui Gallassi and Lars Harrysson
}

\subsection{Introduction}

In this chapter, ageing and migration is placed within the setting of international human rights law and its relevance to reducing civic forms of exclusion. International legal treaties are presented within a mobility perspective to assess whether the protection mechanisms of human and labour rights are in line with the international migration movements brought by globalization. With the example of Sweden as a host country, we analyse the principles of equality and non-discrimination as the pillars for the protection of human rights, in order to assess their capacity to support the right to work and the right to social security for ageing migrants. These rights are presented as possessing the characteristics of socio-rights, which can serve to circumvent mechanisms of civic exclusion, in this case socio-cultural processes connected to identity-based and discriminatory practices, and secure better socioeconomic outcomes for older migrants. Finally, the consequences of the difficulties experienced by migrants in accessing the formal labour market are analysed to evaluate the need for further legislation and policy to support the rights of this group. As illustrated by Pickett and Wilkinson (2009), equal societies perform better in regards to inclusion, and as Therborn (2012) harshly notes, inequality provides a "killing field" for the cohesion of societies. Socio-economic status, as discussed in this chapter, represents a strong force in both social inclusion and social exclusion, and thus an important aspect of any person's sense of civic positionality in a society, or lack thereof. If, as our empirical example illustrates, systems that are introduced to provide income support serve instead to widen the income inequality gap, groups

\author{
A. Lui Gallassi $(\varangle)$ \\ Örebro University, Örebro, Sweden \\ e-mail: ada.lui-gallassi@oru.se \\ L. Harrysson \\ Lund University, Lund, Sweden
}


with low- or erratic-income histories, like many migrants in Sweden, are specifically vulnerable to the impacts of socio-cultural based processes that can undermine their civic and social positionality and status.

\subsection{Principle of Equality and Non-Discrimination - Pillars for the Protection of Human Rights}

International human rights law has created several mechanisms to combat human rights violations and to protect a vast number of basic fundamental rights. It intends to universally preserve and protect such rights (Lechner and Boli 2008) by transcending national borders. This is one of its' most important aspects, and means that the international setting of human rights law incorporates variations of culture and tradition in national legal systems and citizenship (Alston and Goodman 2013). In analogy with Hannah Arendt (Arendt 1979) and her argument on human rights and citizenship, international human rights law aims at providing individuals the "right to have rights', where 'belonging to humanity' (Hamacher and Wetters 2004) is the one and sole relevant criteria to be entitled to rights.

The idea of a common world culture is conveyed through the intensified globalization that the world is currently experiencing (Friedman 2007), in which place of birth, origin, or residence should not interfere with one's fundamental rights (Nussbaum 2010). As a result, concepts of transnationalism and cultural pluralism, as well as cosmopolitanism versus localism, are central to a debate and understanding of the global migration phenomenon (Friedman 2007). Values such as human rights are essential to this global community (Held 1995).

The principles of equality and non-discrimination, enshrined as preamble articles to the various international human rights treaties, are central to the inclusive universality of human rights. ${ }^{1}$

When discussing the principle of equality, it is important to ask ourselves what we mean by the term. Our standpoint rests in Amartya Sen's way of linking equality to "our capability to achieve valuable functioning that make up our lives, and more generally, our freedom to promote objectives we have reasons to value." (Sen 1992, p. xi). What are the conditions for human rights law to encompass the idea that everyone should be treated equally before the law? In an attempt to answer this question there are two approaches to the principle of equality that we will take into consideration, namely formal equality and substantive equality. Formal equality establishes equal treatment to everyone in similar or equal cases. Substantive equality considers material differences and employs a difference in treatment between groups or individuals (e.g. positive discrimination) that, due to their status or

\footnotetext{
${ }^{1}$ These principles are not only included in all the core international human rights instruments, but also in several specialized human rights and labor rights conventions.
} 
specific conditions, is required to achieve equal outcomes, de facto equality (Moeckli 2010; Sageant 2018).

For the purpose of achieving the core ideal of human rights, and because ageing migrants are a specific group, the two approaches tend to live parallel lives. Sen (1992) argues that the principles do have a tendency to be in conflict when politicised. In practice however, they often exist on different levels. The formal equality approach safeguards the "sameness" of people on an institutional level, while the substantive equality approach focuses on the aim and ideal to "try to correct the wrong" and in taking into account the reality of the position of ageing migrants on a concrete practical level. Sageant (2018) argues for the latter to be the more appropriate approach to utilise when considering the circumstances of older migrants. Thus, for the realization of de facto equality, it is in many occasions necessary to establish positive discrimination policies in order to equalize the conditions of the less favoured group or individual in a given society. For instance, this is employed in many countries in relation to employment practices through quota schemes that ensure representation of disadvantaged groups e.g. indigenous populations and other minority groups (Smith 2007).

Both approaches, formal and substantive equality, are likely to be powerful instruments in securing equality of treatment for older migrants, thereby reducing a core set of exclusionary outcomes.

The principle of non-discrimination is particularly relevant for groups in vulnerable positions. The empirical study referred to in this chapter clearly indicates how migrants in Sweden may end up in precarious economic situations as a result of lacking labour market integration. Possessing problematic working life trajectories can enhance exclusionary experiences in later life, illustrating a lack of "aligned biographies" (Bommes 2000). Then we look into the International Covenant on Economic, Social and Cultural Rights (ICESCR), ${ }^{2}$ the articles regarding nondiscrimination are viewed as a core principle to the treaty as a whole and specifically provides the inclusive focus behind the Covenant (see art. 2.2 ICESCR). Even though the principle of non-discrimination comes as a separate right and article in international human rights law, the goal behind it and the principle of equality is very similar in essence. Furthermore, the protection of members of minorities against discrimination and the goal to achieve the vital concept of equality are central concerns for most liberal nation-states (Alston and Goodman 2013, p. 526).

Two important aspects of discrimination concerning ageing migrants are highly relevant to civic forms of exclusion in many western nations; discrimination based on older-age and discrimination based on race/ethnicity and nationality. In combination, they lead to increasingly precarious living conditions for people belonging to both groups, not least to ageing migrants. In line with understandings of sociocultural exclusion, these dimensions of discrimination can reduce older migrants to single identities, excluding them from expressing their intersectional and complex

\footnotetext{
${ }^{2}$ The International Covenant on Economic, Social and Cultural Rights (ICESCR) is considered a core legally binding instrument of international human rights law for socio-economic rights, which is the focus of this chapter.
} 
selves, and excluding them from adequate representation of their personhood. Allowing these principles to be part of a policy judgement tool for evaluation of social protection models would help illuminate systematic tendencies towards increased exclusionary consequences. They would serve as warning signals when distributive effects of a system may strengthen inequality, thus expose people to social exclusion.

\subsection{Work and Social Security as Benchmarks of Inclusion}

The right to work and the right to social security (protection) ${ }^{3}$ are part of the socalled social rights established by international human rights treaties. ${ }^{4}$ They are crucial provisions to ensure basic democratic rights to promote socio-economic integration and to combat exclusion of ageing migrants in the host countries. As defined by Marshall, social rights are "the whole range from the rights to a modicum of economic welfare and security to the right to share to the full in the social heritage and to live the life of a civilized being according to the standards prevailing in society" (Marshall 2006, p. 30).

Regarding the right to work, apart from the basic idea that everyone should have the right to work or to engage in a productive activity, this right also underlines the importance of having "access to employment, freedom from forced labour, and security in employment" (Smith 2007, p. 280). In other words, this refers to the right to adequate employment, with a decent wage, under the minimum international labour standards. The right to work and its related rights are established in several international human rights and labour standards treaties, i.e. Universal Declaration of Human Rights (UDHR) and International Covenant on Civic and Political Rights (ICCPR) among others. Analysing this right for ageing migrants through the lenses of equality and non-discrimination means, "the realization of the right to work implies equal access to employment, equal opportunities for promotion, and equality in terms and conditions of work" (Smith 2007, p. 282). Following the goal of de facto equality, to overcome the disadvantages within the ageing migrant group, positive discrimination, or affirmative action measures should be taken into account to remedy any inequality of opportunity faced by this group. Of course, some restrictions or discrimination based on national origin for instance may still exist based on the type of work accessible to older migrants, such as limited opportunities to undertake public administration jobs with an increased security level.

Let us then move to our example, the Swedish case of social protection - the right to work and to a retirement income.

\footnotetext{
${ }^{3}$ It is important to note that from an international legal setting, social protection and social security rights are seen as synonyms and can have interchangeable meanings - see CESCR (2008, para. 4).

${ }^{4}$ See the International Covenant on Economic, Social and Cultural Rights (ICESCR).
} 


\subsection{Social Protection, Equality and Non-discrimination in Sweden}

Sweden has signed several international human rights treaties that guarantees the right to equality and non-discrimination. Examples are the International Covenant on Civil and Political Rights and the International Covenant on Economic, Social and Cultural Rights, the International Convention on the Elimination of All Forms of Racial Discrimination (ICERD) and the Convention on the Elimination of All Forms of Discrimination against Women (CEDAW). Against this legal backdrop, let us explore the right to work and to have a retirement income, and the principles of equality and non-discrimination in addressing forms of civic exclusion that can impede the achievement of these rights. Our focus is on migrants and inclusionary and exclusionary patterns in relation to ageing.

'I have never during my 26 years in Sweden ... never met one single immigrant who has said that - I don't want to work in Sweden. /.../ the question rather is: How does the structures in society look, and what preconditions and opportunities are there for a person to be part of the labour market?' (Social worker, interview)

As claimed by international legal instruments, based on the principles of equality and non-discrimination, the right to work and the right to social security should be ensured equally for people legally within its jurisdiction, citizen or not. Even though Sweden has developed an inclusive policy towards migration and enacted the various anti-discrimination laws, the tendency towards marginalization of the migrant population in society, and the difficulties for the migrant group in gaining access to employment, particularly white-collar jobs, is an ongoing fact (Castles et al. 2014). According to Woolfson et al. (2014) even migrants holding a work permit in Sweden, either temporary or linked to an employer, encounter abuse by employers. This has detrimental impacts on labour ties and working conditions, creating new spaces for migrant precariousness. The vulnerabilities linked to such precarious working conditions and a lack of labour standards guaranteeing access to decent work and strong employment ties bring consequences such as instability, poor social protection, insecurity and socio-economic exclusion. It contradicts the right to work and the right to social security (Anderson 2013). This becomes particularly clear in a retirement perspective where a life-time-earnings-based system (see below) is prevalent, thus making latecomers' situation difficult. The ageing migrant's position, other things equal, relatively worsens as time goes by (Harrysson et al. 2016).

There is a strong relationship between the right to paid work and the right to social security, as the latter is considered a direct consequence of the right to work, being based on labour market participation and taxable income. This is particularly the case in relation to benefits linked to illness, disability, maternity, employment, injury, unemployment, old-age, or death of a family member (CESCR, General Comment 19, para. 2). A broader definition of social security rights also encompasses social assistance, moving from an individual right to a "collective allembracing right" (Nussberger 2007). For the scope of this chapter, the right to social 
security solely refers to the individual right to social protection benefits after retirement due to old-age.

The importance of the right to social security lies in that while it provides a social safety net, it also has positive impacts on income equality and in combating poverty (Ben-Bassat and Dahan 2008, p. 108). This right is seen as one out of the five social rights that should be included in a Constitution, to ensure the 'right to live in dignity'. (ibid, p. 105). For the Universal Declaration of Human Rights, this right is considered a core guarantee for the right of everyone to an adequate standard of living (Art.25 UDHR). According to the International Labour Organization, "Social Security systems are one of the most powerful institutional expressions of social solidarity." (International Labour Office 2011, p. 71). Social protection benefits are essential mechanisms to eliminate socio-economic exclusion and marginalization in society. As outlined by Claudio Bolzman, "given the development and growth of the welfare state, social security has become the main means of protecting individuals from poverty and insecurity" (Bolzman 2012, p. 105). To those with migrant backgrounds, first generation Swedes, lacking "aligned biographies" (Bommes 2000), the inclusion in these systems is vital for integration, and clearly the opposite if actively excluded as victims of discriminatory systems and/or stigmatizing political discourses. We will next use an empirical example of the lived experience of this system, the manifestation of key exclusionary processes that are rooted in civic dimensions, and the consequences for socio-economic outcomes.

\subsection{Retirement in Sweden: A Lived Experience}

Retirement in Sweden, as in other western economies, relates to moving into a decommodified part of life, a time when we do not need to think of earning our living through paid work (Esping-Andersen 1990). However, retirement is strongly related to long-term dependence on paid work, as we live the consequences of our working life trajectory. A trajectory should illustrate how we prepare for our lives in later life. However, financial preparations, commonly discussed in terms of individual choices, are choices made in a context of specific system requirements. In the pension system these requirements regard both time spent in Sweden and incomes earned and taxed, as well as type of employment contracts in play. Many migrants do not meet them as they deviate from the expected life course in three central dimensions: education, employment and retirement (Harrysson et al. 2016). In these dimensions our life inclusion outcomes are dependent on national welfare institutions providing protection to us as their members.

The data collection for the study (Harrysson and Werner 2015), which this chapter draws on, was carried out in the southern Swedish city of Helsingborg. It was an action research inspired project in which migrants who arrived in Sweden in the 1990s and later reflected upon how they navigate and form strategies to handle the retirement and pension contexts. The study was based on individual and group interviews with migrants of mostly non-European origin, who arrived in Sweden while 
of working age. We also interviewed and had workshops with professionals in social work and social insurance as well as private insurance and banking. Some of the respondents were already retired, most were not. Data collection focused on general experiences of migration, work, family life, health and economy. The empirical data demonstrated significant complexity in the migration process and a diversity in retirement preparations that reflect biographies that do not conveniently fit into institutionalised expectations. These participants found themselves in a transitional position as job seekers, where they often had been for quite some time, and often as a group at risk of receiving low pensions in the future (Harrysson et al. 2016).

The Swedish public pension system, as referred to among pension researchers, is based on notional individual accounts (fictive savings) providing accrued pension rights on a lifetime income principle and assumes that a person is independent of their spouse in most respects. The income and premium pensions are fully portable and may be drawn from more or less anywhere in the world where there is a banking system. They are intended to cover about $60-70$ per cent of final income for those also drawing a pension from an occupational benefit scheme, which is a part of collective agreements in the labour market in Sweden. However, as Harrysson et al. argues, the "generous" part of the system's design is not typically accessible to people with limited opportunities to build up pension rights, such as migrants arriving in Sweden in later life or those with only intermittent access to paid work in a workplace with a collective agreement. These latter groups are instead dependent on the other part of the public pension system that takes the form of paid supplements, e.g. guaranteed pension and maintenance support for pensioners. Such supplements are limited in their portability, thus forcing people to stay in Sweden to receive longterm payments. They are also restricted by factual residency. "This attribute of the Swedish pension system reflects a historically well-established duality of the Swedish welfare state. The advantage of a relatively generous social insurance in terms of income maintenance with less individualised social control /../, is balanced by a tradition of poverty relief with quite harsh restrictions on mobility /../." (Harrysson et al. 2016, p. 535).

The consequence of a labour market not absorbing newly arrived groups, and existing labour market policies not facilitating a more appropriate integration of migrants into paid labour, will be low pensions. Many older migrants participating in this research were well aware of this:

'The pension system is not made for foreigners, it is made for Swedes who work here, live here and die here.' (Focus group with migrants)

Pension levels very close to the relative poverty line, defined as older people that may not have enough resources to buy four necessary items, are reported by Pensionsmyndigheten to be the case for around 245,000 individuals (approx.12\%) and this in large is explained by how the system is designed (Pensionsmyndigheten $2019 \mathrm{a}, \mathrm{b}$ ). The poverty measure used combines the levels of guaranteed pension and income maintenance support with housing subsidies. However, many older people pay low rent, and thus are not eligible for such rental subsidies. This is not exclusively a case for migrants, but all persons having had erratic working life trajectories 
may encounter the very same situation. The system's core is an income-related pension, which is strongly connected to lifetime earnings. This is in terms of an evenly distributed income over a working life. The public system does not generate pension rights on incomes above 538,700 SEK or below 20,008 SEK in 2020 (Pensionsmyndigheten, 2020). Thus, a short time in the labour market and an uneven income distribution (below the threshold in some years and above in other years) is not favoured by the system. The introduction of an income maintenance support scheme with an intention of freeing people from means testing procedures of social assistance, has not altered its historical foundation in poverty relief and locking in effects (Harrysson et al. 2016).

'If I, for example, have worked in the health care here in Sweden, then I have only worn down my body. I don't earn any pension. Maybe I should have been a housewife instead, then I would have received 6000 crowns anyway! It would have been better if I had these thoughts today, then I wouldn't have worked a day and still have the right to the 6000.' (Focus group with migrant women)

In sum, the pension system does not discriminate in its design on anything but income, but shows some awkward negative consequences for people not fitting the model citizen upon which the system is designed. At the same time, the system is positively discriminating some particular life situations as to withstand unwelcome effects on pension equality. Time off work due to childbearing, military services and higher education provide some pension credits. Further, as the social insurance schemes concerning unemployment, sickness, occupational injury and parental leave are income-compensating systems, pension credits are counted as equal to wage incomes. Since these insurances all have eligibility rules, capped entitlements and defined durations, their strength as social protection mechanisms for older migrants can be questioned (Harrysson and Werner, 2015).

'Pension!, but that is nothing but social assistance by another name.' (Man (not ironically) telling us that his job is to search for jobs)

'... you are Einstein, Aristotle and Plato, but you don't get a job! Bueno, full stop.' (Focus group with women)

The system's strong focus on lifetime income has also shown a disadvantage to women in those generations planning within the former system, which focused on the best 15 of 30 years of wage earnings as eligibility criteria for an adequate pension level. Staying at home to care for children or working part time does not pay off in the new system's eligibility rules in the same way. However, for some migrant women, the system, as individualized as it is, has provided them with a personal income that they never before had access to as they were dependent on their husbands' incomes (Harrysson and Werner, 2015). 


\subsubsection{Living Unequal Outcomes}

First generation migrants do not fit the standard case of a Swedish retirement planner. Despite that, the system is intended to treat all entrants the same. The effects of a life-income-based savings system causes large variations in subsistence opportunities among groups of legally residing people in Sweden. Seen in a perspective of subsistence, which is what people mostly think of when pensions are discussed (Harrysson and Werner 2015), it often opposes a pure insurance argument.

However, we would argue that the system in itself is not discriminatory towards migrants as such, but rather positively discriminating groups with shorter time in Sweden. This is because the system is in effect compensating for a lack of eligibility in terms of required years of contribution (40 years of contributions required for full guarantee pension) through an income maintenance system.

Harrysson and Werner argue that those that are really hit by the system's way of working are people with erratic income patterns over life, earning only a guaranteed pension after a full working life in Sweden. This situation fuels a populist argument against migrants' rights to income maintenance, regardless of the very low levels of support provided. In this regard, such arguments do not help foster a better understanding of the precarious position that many migrants find themselves in due to major difficulties in entering the labour market in the first place, and due to typically having to work in sectors paying less and with worse working conditions.

In a worst-case scenario people are forced to work in the black market not earning any public pension rights at all. Combined with this we find the issue of migrants being less informed of what is expected and what is required to build pension rights. In some respects people live in a "vacuum" judging their situation from a standpoint founded in their former home country's cultural setting and system, and in myths, arguably wrong, about how the Swedish system works (Harrysson and Werner 2015). But still, people were adamant about the need for not giving up:

\footnotetext{
Participant 1: 'Sure, it is the question, but what other solutions are there? Life goes on and you can become bitter, but you can't stay bitter because then your whole life "marshy", what do you then make of it, what solutions are there? Family ties for example - family, the collective. How do you do to make life go on? These are things you think of when you see that the safety net which is there doesn't produce any cover.'
}

Participant 2: 'Well put. You compensate.'

(Focus group with men)

\subsection{Conclusion}

This chapter highlights the overall challenges in relation to the right to work and the right to social protection, from the perspective of equality and non-discrimination, for ageing migrants in Sweden. It also highlights how socio-cultural processes connected to identity-based and discriminatory practices, can drive these challenges, 
impacting socio-economic outcomes and, to a degree, civic and social positionality for older migrants. Based on a case derived from a research project concerning migrants and pensions in a Swedish municipality, we can conclude that the system in Sweden in many cases uses positive discrimination and de facto equality to provide a more equal and non-discriminated right to social security. But the problems experienced by ageing migrants regarding social protection benefits, particularly the retirement pension, consequentially lies in the right to work and taxed wage income during the course of their working life trajectory. As the retirement pension is based on taxed wage income and years worked in Sweden, it is necessary to find ways to tackle discrimination and to achieve de facto equality regarding access to the formal labour market. The chapter connects socio-economic status and conditions of ageing migrants to civic, and broader forms of social exclusion, highlighting the impacts of these processes for person's sense of status in a society. This also requires policy initiatives to combat increasing cleavages between social groups, which are in this case propelled by migrants' experiences of structurally instituted exclusion during their working life, negatively impacting socio-economic outcomes in later life.

Finally, this chapter signals the importance of a future research agenda on the interaction of the various aspects of the working life trajectory of migrants and what that means for social exclusion in later life. It also highlights directions for a legislation on the right to work and the right to social security, envisioning equality and non-discrimination for ageing migrants in society.

\section{Editors' Postscript}

Please note, like other contributions to this book, this chapter was written before the COVID-19 pandemic of 2020. The book's introductory chapter (Chap. 1) and conclusion (Chap. 34) consider some of the key ways in which the pandemic relates to issues concerning social exclusion and ageing.

\section{References}

Alston, P., \& Goodman, R. (2013). International human rights. The successor to international human rights in context: Law, politics and morals. Oxford: Oxford University Press.

Anderson, B. (2013). Us and them? The dangerous politics of immigration control. Oxford: Oxford University Press.

Arendt, H. (1979). The origins of Totalitarism. San Diego: Harvest.

Ben-Bassat, A., \& Dahan, M. (2008). Social rights in the constitution and in practice. Journal of Comparative Economics, 36, 103-119.

Bolzman, C. (2012). Democratization of ageing: Also a reality for elderly immigrants? European Journal of Social Work, 15(1), 97-113. 
Bommes, M. (2000). National welfare state, biography and migration. Labour migrants, ethnic Germans and the re-ascription of welfare state membership. In M. Bommes \& A. Geddes (Eds.), Immigration and Welfare, Challenging the borders of the welfare state (pp. 90-108). Routledge/EUI studies in the Political Economy of Welfare.

Castles, S., de Haas, H., \& Miller, M. J. (2014). The age of migration: International population movements in the modern world. Basingstoke: Palgrave Macmillan.

Esping-Andersen, G. (1990). Three worlds of welfare capitalism. Cambridge: Polity Press.

Friedman, J. (2007). Global systems, globalization, and anthropological theory. In I. Rossi (Ed.), Frontiers of globalization research: Theoretical and methodological approaches (pp. 109-132). New York: Springer Science+Business Media.

Hamacher, W., \& Wetters, K. (2004). The Right to Have Rights (Four-and-a-Half Remarks). The South Atlantic Quarterly, 103, 343-356. https://www.muse.jhu.edu/article/169144.

Harrysson, L., \& Werner, E. (2015). Begriplig pensionsinformation för dem med små inkomster. En rapport från ett projekt om hur pensionsinformation begripliggörs bland migranter $i$ Helsingborg. Lund. Sweden: Research Reports in Social Work - Lund University, School of Social Work.

Harrysson, L., Werner, E., \& Montesino, N. (2016). Preparations for retirement in Sweden: Migrant perspectives. Critical Social Policy, 36(4), 531-550. https://doi. org/10.1177/0261018316638081.

Held, D. (1995). Democracy and the global order : From the modern state to cosmopolitan governance. Cambridge: Polity Press.

International Labour Office. (2011). Social security and the rule of law. Geneva: International Labour Organization.

Lechner, F. J., \& Boli, J. (2008). World culture: Origins and consequences. Oxford: Blackwell publishing.

Marshall, T. H. (2006). Citizenship and social class. In C. Pierson \& F. Castles (Eds.), The welfare state reader (pp. 30-39). Cambridge: Polity Press.

Moeckli, D. (2010). Equality and non-discrimination. In D. Moeckli, S. Shah, \& S. Sivakumaran (Eds.), International human rights law (pp. 189-208). New York: Oxford University Press.

Nussbaum, M. (2010). Patriotism and cosmopolitanism. In G. W. Brown \& D. Held (Eds.), The cosmopolitanism reader (pp. 155-162). Cambridge: Polity.

Nussberger, A. (2007). Interpretation of international social security standards - Problems and prospects. In F. Pennings (Ed.), International social security standards. Current views and interpretation matters (pp. 33-51). Antwerpen $\backslash$ Oxford: Intersentia.

Pensionsmyndigheten. (2019a, 10 04). Ny rapport: Äldre med låga inkomster 2018. Retrieved from www.pensionsmyndigheten.se. https://www.pensionsmyndigheten.se/nyheter-och-press/ pressrum/ny-rapport-aldre-med-laga-inkomster. Accessed 12 Aug 2019.

Pensionsmyndigheten. (2019b, Oct 04). Pensionsmyndigheten. Retrieved from https://www.pensionsmyndigheten.se/forsta-din-pension/om-pensionssystemet/sa-beraknas-din-pension-basbelopp-och-varderegler Accessed 12 Jan 2020.

Pickett, K., \& Wilkinson, R. (2009). The spirit level: Why more equal societies almost always do better. London: Allen \& Unwin.

Sageant, M. (2018). Discrimination and the law. New York: Routledge.

Sen, A. (1992). Inequality reexamined. Oxford: Clarendon Press.

Smith, R. K. (2007). Textbook on international human rights. New York: Oxford University Press.

Therborn, G. (2012). The killing fields of inequality. International Journal of Health Services, 42, 579-589.

Woolfson, C., Fudge, J., \& Thörnqvist, C. (2014). Migrant precarity and future challenges to labour standards in Sweden. Economic and Industrial Democracy, 35(4), 695-715. 
Open Access This chapter is licensed under the terms of the Creative Commons Attribution 4.0 International License (http://creativecommons.org/licenses/by/4.0/), which permits use, sharing, adaptation, distribution and reproduction in any medium or format, as long as you give appropriate credit to the original author(s) and the source, provide a link to the Creative Commons license and indicate if changes were made.

The images or other third party material in this chapter are included in the chapter's Creative Commons license, unless indicated otherwise in a credit line to the material. If material is not included in the chapter's Creative Commons license and your intended use is not permitted by statutory regulation or exceeds the permitted use, you will need to obtain permission directly from the copyright holder. 